\title{
Implementasi Framework Zachman sebagai Metodologi Terstruktur Perancangan Learning Management System
}

\author{
Zachman Framework's implementation as a Structured Methodology on \\ Designing Learning Management Systems
}

\author{
Hanifatus Sa'diyah*1, Bambang Soedijono ${ }^{2}$, Bambang M. Rudyanto Arief ${ }^{3}$ \\ 1,2,3 Magister Teknik Informatika Universitas Amikom Yogyakarta \\ E-mail: *1hanifatus.w@students.amikom.ac.id, ${ }^{2}$ bambang.s@amikom.ac.id, \\ ${ }^{3}$ rudy@amikom.ac.id
}

\begin{abstract}
Abstrak
Perkembangan teknologi yang memasuki era internet of thing saat ini semakin diminati di setiap elemen masyarakat. Salah satu perkembangan teknologi yang telah diterapkan adalah learning management system guna menunjang sarana pendidikan di Indonesia. Kesempatan pengembangan perangkat LMS masih sangat terbuka, namun para developer lokal di Indonesia masih belum dapat melihat peluang dan tantangan yang ada sehingga menyebabkan minimnya LMS lokal di Indonesia. Metode analisis penelitian ini menggunakan Framework Zachman yang merupakan salah satu metode Enterprise Architecture Planning (EAP) yang digunakan untuk perancangan sistem dengan cara menyajikan langkah yang sistematis, mudah dipahami, dan dapat dijadikan kontrol untuk pengembangan sistem dimasa mendatang. Penelitian ini menghasilkan blueprint learning management system yang dipetakan kebentuk matrik Zachman yang mewakili sudut pandang penggagas AKRB Yogyakarta, sudut pandang pemilik yaitu instansi pendidikan, dan sudut pandang pengembang yaitu sistem analis sehingga menghasilkan arsitektur data yang disesuaikan dengan aktifitas proses pembelajaran yang berjalan di AKRB Yogyakarta yaitu mencakup data dosen, data mahasiswa, data mata kuliah, data materi kuliah, dan data tugas perkuliahan, serta desain jaringan yang telah disesuaikan dengan kebutuhan.
\end{abstract}

Kata Kunci — Teknologi Informasi, Learning Management System, Framework Zachman

\begin{abstract}
The development of technology that has entered the internet of things era is increasingly in demand in every element of society. One of the technological developments that has been implemented is the learning management system to support educational facilities in Indonesia. The opportunity to develop LMS devices is still very open, but local developers in Indonesia still cannot see the opportunities, leading to the lack of local LMS in Indonesia. The method of analysis of this study uses the Zachman Framework which is one of the Enterprise Architecture Planning (EAP) methods used for system design by presenting steps that are systematic, easy to understand, and can be used as controls for future system development. This study resulted in a blueprint learning management system that was mapped to the Zachman matrix which represented the viewpoint of the Yogyakarta AKRB initiator, the owner's point of view, the educational institution, and the developer point of view that the system analyst produced a data architecture adapted to the learning process activities in the Yogyakarta AKRB includes lecturer data, student data, course data, lecture material data, and lecture assignment data, as well as network design that has been tailored to the needs.
\end{abstract}

Keywords - Information Technology, Learning Management System, Zachman Framework 


\section{PENDAHULUAN}

Perkembangan teknologi yang memasuki era internet of thing saat ini makin diminati. Aktifitas di setiap elemen masyarakat yang awal mulanya dilakukan di dunia nyata mulai berpindah ke dunia digital dengan adanya penerapan teknologi. Hadirnya penggunaan teknologi telah menyebabkan disrupsi diberbagai keseharian masyarakat, salah satunya pada aspek pendidikan yaitu media pembelajaran. Media pembelajaran berbasis teknologi diyakini mampu menyelesaikan berbagai permasalahan proses pembelajaran seperti keterbatasan modul pembelajaran cetak, keterbatasan pengajar, minimnya jam pertemuan, dan mampu mengatasi jarak yang jauh, ruang maupun waktu yang berbeda. Pembelajaran yang menggunakan perangkat elektronik sebagai sarana penunjang proses pembelajaran disebut E-learning [1].

Salah satu penunjang utama perangkat e-learning adalah perangkat learning management system atau sering disebut LMS. LMS menjadikan pembelajaran lebih efektif karena proses pembelajaran akan berpusat pada pelajar. Pelajar memungkinkan akses modul pembelajaran tak terbatas dengan jarak, waktu dan ruang sehingga mengoptimalkan proses pembelajaran [2].

Begitu besar peranan LMS terhadap aspek pendidikan khususnya proses pembelajaran. Kesempatan pengembangan perangkat LMS masih sangat terbuka, namun para developer lokal di Indonesia masih belum dapat melihat peluang dan tantangan yang ada. Hal ini menyebabkan minimnya LMS lokal di Indonesia dan menjadikan beberapa perusahaan dan instansi pendidikan lebih menggunakan platform LMS buatan luar negeri seperti Moodle dan Claroline.

Platform Moodle dan Claroline buatan luar negeri yang saat ini lebih banyak digunakan oleh instansi pendidikan tidak terlepas dari berbagai macam kekurangan. Kekurangan platform LMS yang dikembangkan oleh para negara maju adalah ketidaksesuaian dengan budaya pendidikan Indonesia. Hal ini dibuktikan dengan ketidakmampuan sistem untuk menampung salah satu sistem pendidikan di Indonesia yaitu sistem pengaturan satuan kredit semester (SKS). Oleh karena itu diperlukan pengembangan LMS yang mencakup budaya pendidikan Indonesia yaitu pengaturan satuan kredit semester.

AKRB Yogyakarta merupakan salah satu Instansi Pendidikan di Yogyakarta yang berfokus pada bidang Ilmu Komunikasi. Sistem belajar mengajar yang telah berjalan selama ini terkendala dengan akses modul pembelajaran yang masih terbatas dengan dimensi jarak, ruang dan waktu. Pelajar harus mendatangi ruang belajar pada waktu yang telah ditentukan untuk mendapatkan modul pembelajaran. Hal ini menjadikan proses belajar mengajar tidak maksimal, mengingat saat ini telah memasuki era digital yang segalanya menjadi tidak terbatas, baik dalam hal jarak, ruang, maupun waktu.

Demi memaksimalkan proses belajar mengajar dan kebutuhan kesesuain LMS dengan sistem pendidikan di Indonesia, maka diperlukan arsitektur LMS yang baru. Dengan desain arsitektur yang disesuaikan dengan sistem pendidikan di Indonesia menjadikan kinerja dan performa LMS akan lebih optimal sehingga tidak terjadi adanya dependensi dengan LMS yang saat ini ada seperti Moodle dan Claroline.

Penelitian mengenai perancangan arsitektur LMS sebelumnya telah dilakukan oleh Taofik dan Mustafa dkk. Penelitian ini telah menguraikan secara detail desain arsitektur LMS yang akan dibangun dengan tujuan untuk membantu dan mempermudah proses belajar dan mengajar. Namun dalam perancangan desain dan arsitektur tersebut tidak menyebutkan pendekatan metodologis yang digunakan [3] [4].

Untuk membuat desain dan arsitektur LMS yang disesuaikan dengan pendidikan di Indonesia tidak mudah. Diperlukan adanya pendekatan metodologis sehingga menjadikan rancangan blueprint sistem LMS tepat dan terarah. Kebutuhan metodologis terstruktur atau framework arsitektur sistem informasi yang memadai untuk perancangan sistem dapat menggunakan kerangka kerja zachman [5]. Kerangka kerja Zachman atau Framework Zachman didefinisikan sebagai salah satu metode Enterprise Architecture Planning (EAP) yang digunakan untuk merancang sistem dengan cara menyajikan tahapan-tahapan yang sistematis, mudah dipahami, serta dapat dijadikan kontrol untuk pengembangan sistem dimasa mendatang [6]. Kelebihan penelitian ini dibanding penelitian yang lain yaitu diterapkannya kerangka kerja atau 
Citec Journal, Vol. 6, No. 1, Januari 2019

ISSN: 2460-4259

framework zachman sebagai metodologis terstruktur pada perancangan arsitektur LMS, sehingga menghasilkan blueprint sistem yang tepat dan lebih terarah. Perancangan LMS berdasarkan kerangka kerja Zachman yang dibangun akan berfokus pada kolom data, proses, dan network yang digambarkan pada Gambar 1 berikut ini.

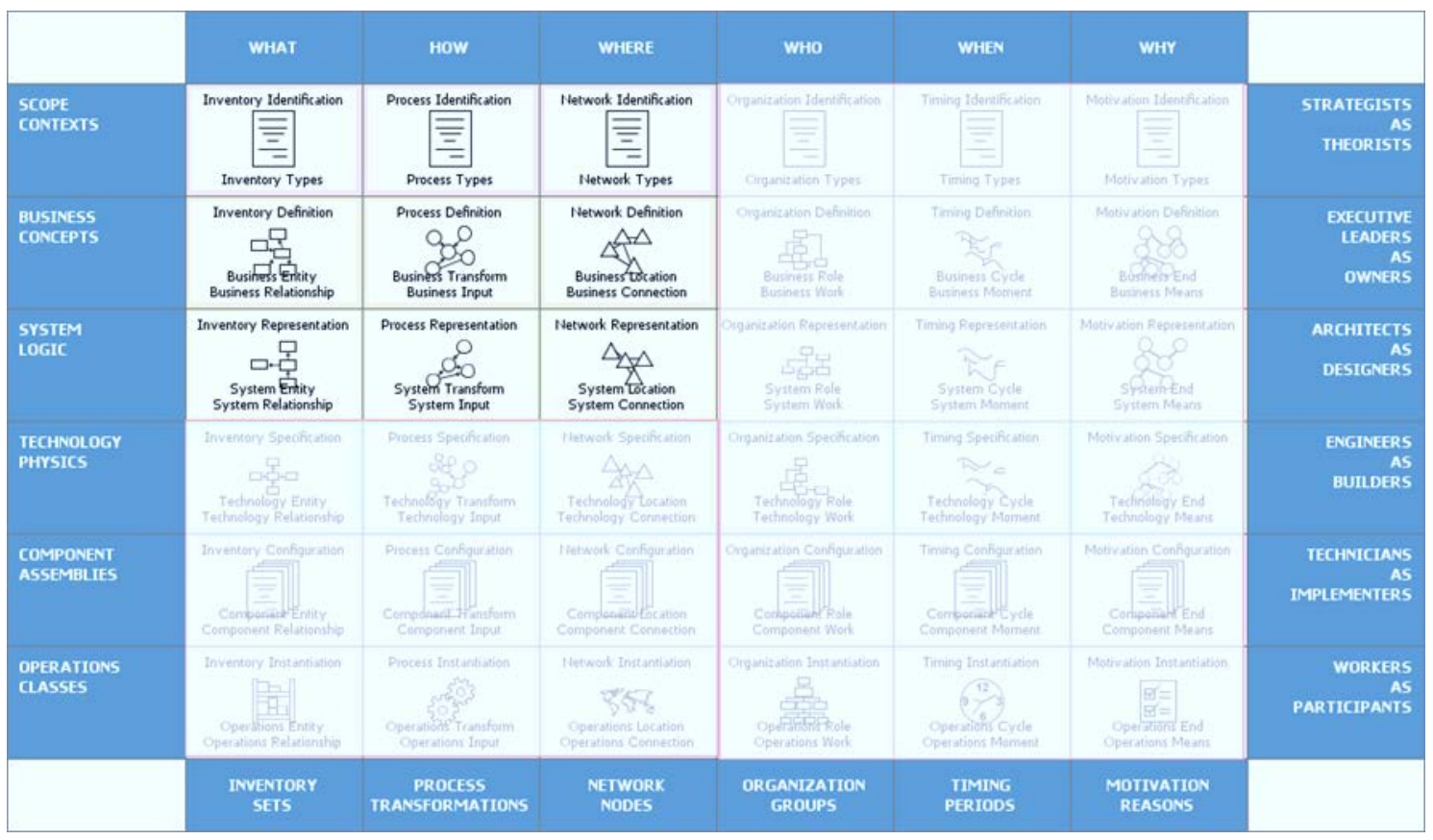

Gambar 1. Ruang Lingkup Framework Zachman

\section{METODE PENELITIAN}

Penelitian ini menggunakan pendekatan kualitatif. Penelitian kualitatif dengan analisis desktiptif digunakan oleh peneliti untuk mengupayakan suatu penelitian dengan cara menggambarkan informasi yang akurat mengenai fakta dari peristiwa yang ditemukan dilapangan terkait proses belajar mengajar dan bagaimana penanganan sistem informasi yang dilakukan. Pengumpulan data diperoleh dengan melakukan wawancara dan observasi. Metode Analisa data menggunakan pendekatan framework Zachman yang akan dijabarkan dalam matrik 3x3. Framework Zachman akan menguraikan arsitektur organisasi dari berdasarkan perspektif ruang lingkup organisasi, model bisnis, dan model sistem informasi. Adapun alur penelitian disajikan secara lengkap pada Gambar 2 berikut. 


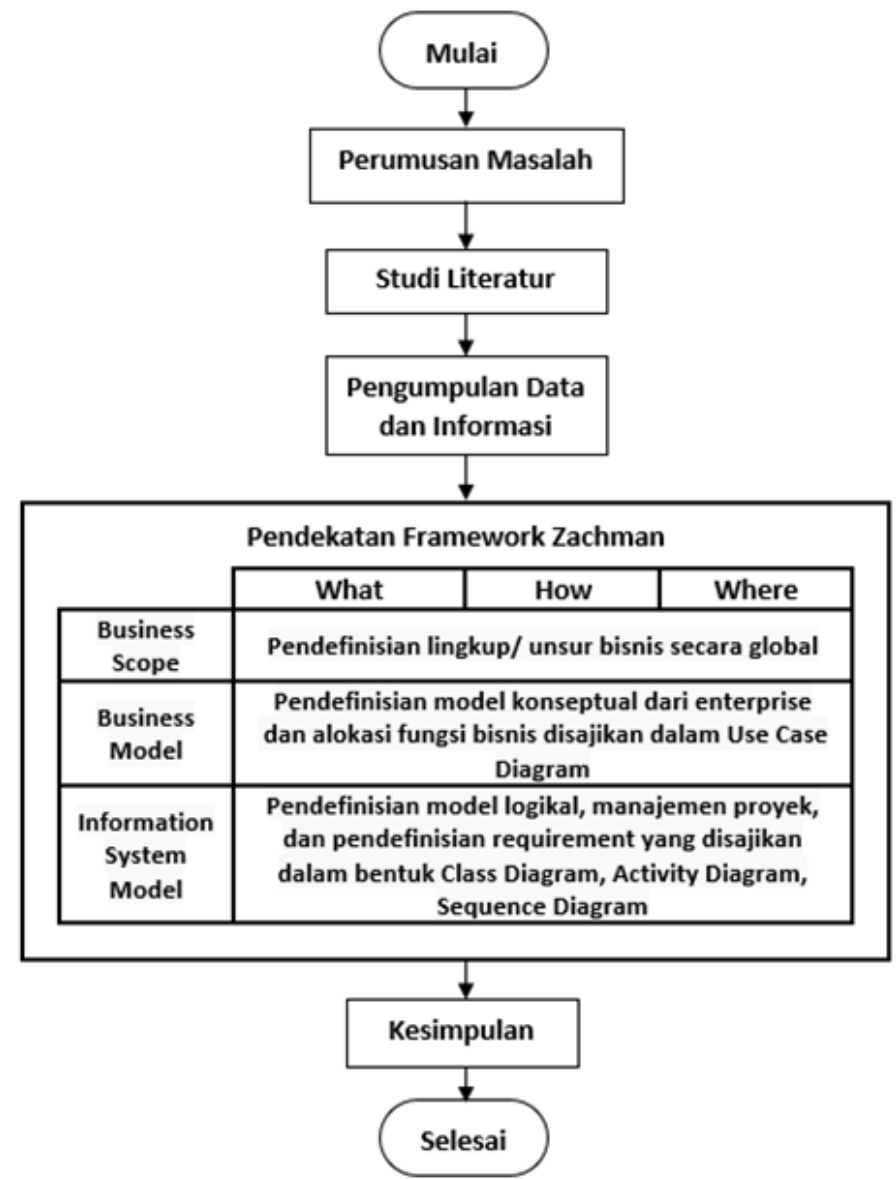

Gambar 2. Alur Penelitan

\subsection{Tinjauan Pustaka}

\subsubsection{Learning Management System}

Learning Management System atau LMS didefinisikan sebagai perangkat lunak atau software yang dipergunakan untuk perencanaan serta pengendalian proses pembelajaran, pengarsipan, pencarian modul pembelajaran, laporan proses pembelajaran yang dapat dilakukan secara online dengan adanya keterhubungan sistem ke internet [7]. LMS menjadikan materi pembelajaran, pengelolaan kegiatan pembelajaran serta hasil pembelajaran bersifat online dan berbasis web sehingga memberikan berbagai kemudahan bagi para pengguna. Hakikat LMS adalah suatu aplikasi yang mengotomasi dan menvirtualisasi proses belajar secara elektronik.

Kemampuan unggulan yang dimiliki LMS sebagai virtualisasi pembelajaran antara lain adalah sebagai berikut[8]:

1. Fungsi Kelengkapan Belajar Mengajar

Fungsi LMS ini mencakup kumpulan mata kuliah dan kategorinya, kurikulum mata kuliah, materi kuliah yang berbasis text atau multimedia, dan kumpulan referensi atau bahan bacaan.

2. Fungsi Diskusi dan Komunikasi

Fungsi diskusi dan komunikasi terdiri dari forum untuk berdiskusi dan mailing list, instant messenger untuk saling berinteraksi secara real-time, papan pengumuman, informasi riwayat hidup instruktur, media komunikasi dengan instruktur, serta file and directory sharing.

3. Fungsi Ujian dan Penugasan

Fungsi ini meliputi ujian yang dilakukan secara online (online examination), tugas secara mandiri (assignment), penilaian dan evaluasi. 


\subsubsection{Kerangka Kerja Zachman}

Kerangka kerja Zachman atau Framework Zachman didefinisikan sebagai salah satu framework yang digunakan untuk mengembangkan suatu enterprise architecture yang telah diperkenalkan oleh John Zachman[9]. Kerangka kerja ini menjadi alat bantu untuk mendokumentasi arsitektur organisasi dari berbagai aspek dan sudut pandang yang berbeda, sehingga akan dihasilkannya gambaran organisasi secara utuh dan menyeluruh. Kerangka kerja Zachman disajikan pada Gambar 3 berikut ini.

\section{The Zachman Framework for Enterprise Architecture "'}

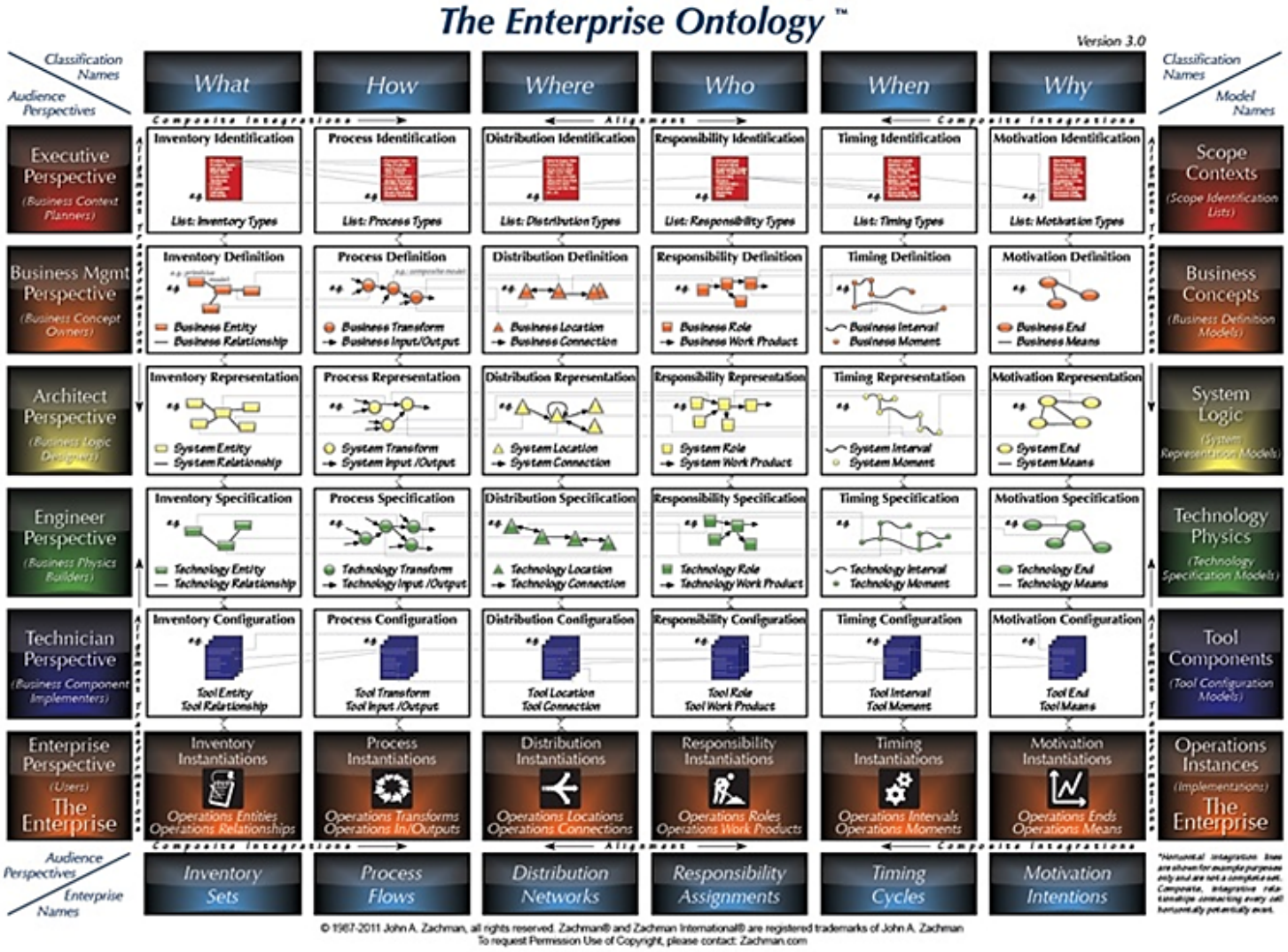

Gambar 3. Kerangka Kerja Zachman

Berdasarkan Gambar 3 yang telah disajikan diatas, Zachman Framework telah mengakomodir berbagai macam perspektif yang berbeda. Berbagai macam perspektif yang berbeda digambarkan dengan matriks $6 \times 6$, dimana 6 baris mewakili perspektif yang berbeda dengan 6 kolom lainnya mewakili aspek organisasi.

Adapun 6 perspektif berbeda tersebut adalah sebagai berikut [10]:

1. Scope (ruang lingkup): Ruang lingkup akan meninjau sistem dari sudut pandang perencana yang mendefinisikan orientasi enterprise dan tujuan bisnis.

2. Enterprise model (model Perusahaan): Enterprise model akan meninjau sistem dari sudut pandang pemilik bisnis atau perusahaan, mendeskripsikan sasaran, strategi, struktur, dan proses yang diperlukan untuk mendukung sistem atau organisasi.

3. System model: Akan meninjau kebutuhan obyek, bagaimana aktifitas yang berjalan dan fungsi sistem pada penerapan model bisnis. Esensi system model ini akan menonjolkan spesifikasi pekerjaan yang dilakukan.

4. Technologi model: Perspektif ini akan memperhatikan batasan atau faktor manusia yang terkait, alat, teknologi dan material yang digunakan. Model teknologi ini sering disebut baris fisik. 
5. Detail representation: Perspektif ini menggambarkan individu, komponen independen yang diperuntukkan bagi para kontraktor untuk dilakukan implementasi sistem.

6. Functioning enterprise: Perspektif fungtioning enterprise menjabarkan sistem operasional yang akan menjadi pertimbangan sebagai salah satu solusi dari suatu permasalahan.

Pemaparan enam aspek organisasi pada framework Zachman adalah sebagai berikut[11]:

1. What (data): Menjabarkan pokok-pokok informasi bisnis, meliputi berbagai macam informasi yang perlu dipelihara. Pada kolom data berisi tiga model data yaitu conceptual data, logical data dan physical data model.

2. How (function): Kolom ini menginterpretasikan berbagai fungsi atau aktifitas yang terjadi. Masukan dan luaran suatu proses menjadi salah satu pokok pertimbangan.

3. Where (networks): Mengindikasikan lokasi geografis dan hubungan antar aktifitas pada suatu organisasi, menglingkupi lokasi geografis suatu perusahaan.

4. Who (people): Menjabarkan siapa saja yang berperan dalam organisasi dan matrik untuk mengukur kemampuan dan kinerja seseorang pada organisasi.

5. When (time): Kolom ini akan meninjau waktu yang menunjukkan kriteria kinerja. Berfungsi untuk menggambarkan jadwal dan mengoperasikan arsitektur sistem pada organisasi.

6. Why (motivation): Menginterpretasikan suatu dorongan atau motivasi dari organisasi dan pekerjaannya. Tampak tujuan, sasaran, target, rencana bisnis kedepan, arsitektur pengetahuan, landasan pemikiran dan pengambilan keputusan pada organisasi.

\section{HASIL DAN PEMBAHASAN}

Perancangan arsitektur LMS akan diselaraskan dengan kerangka kerja Zachman sebagai dasar perancangan sistem. Baris kerangka kerja zachman menginterpretasikan 6 sudut pandang berbeda yang terkait dengan perancangan sistem, yaitu sudut pandang dari perencana (planner perspective), pemilik (owner's perspective), perancang (designer's perspective), pengembang (the builder's perspective), dan sub kontraktor (a sub-contractor's perspective).

\subsection{Baris 1 -Scope Context/Strategist as Theorists}

Pada baris pertama, yaitu scope context menginterpretasikan tujuan dan konsep pengembangan sistem dari sudut pandang pencetus, yaitu instansi pendidikan AKRB Yogyakarta. Baris scope context akan dijelaskan secara mendetail apa saja data yang dibutuhkan, bagaimana proses yang berjalan, dan jaringan/network.

\subsubsection{Kolom Data (What)}

Pada baris scope context untuk kolom data diidentifikasikan data-data apa saja yang terkait dengan LMS. Adapun data yang berkaitan dengan LMS yang akan dibangun mencakup data dosen, data mahasiswa, data mata kuliah, data materi kuliah dan data tugas perkuliahan.

\subsubsection{Kolom Proses (How)}

Pada baris scope context untuk kolom proses mendeskripsikan proses apa saja yang dilakukan didalam LMS. Adapun proses yang terjadi meliputi proses belajar mengajar (kelengkapan proses pembelajaran), proses diskusi dan komunikasi, serta proses latihan, ujian dan penugasan. 
Citec Journal, Vol. 6, No. 1, Januari 2019

\subsubsection{Kolom Network (Where)}

Pada baris scope context untuk kolom jaringan (network) dijabarkan tata letak atau lokasi secara geografis LMS berada yaitu kampus terpadu AKRB Yogyakarta di Jl. Janti No.3/47, Jaranan, Karangjambe, Kec. Banguntapan, Bantul, Daerah Istimewa Yogyakarta 55198.

\subsection{Baris 2 - Business Concepts/Executive Leaders as Owners}

Baris business concepts akan memaparkan sistem dari sudut pandang pimpinan eksekutif sebagai pemilik perusahaan/organisasi (Owner's perspective). Kolom yang akan diuraikan pada baris business model adalah data, proses, dan network.

\subsubsection{Kolom Data (What)}

Baris business concepts untuk kolom data menjabarkan secara rinci informasi dari setiap objek. Gambar 4 berikut adalah uraian informasi bagaimana interaksi user dengan fungsi-fungsi LMS pada system

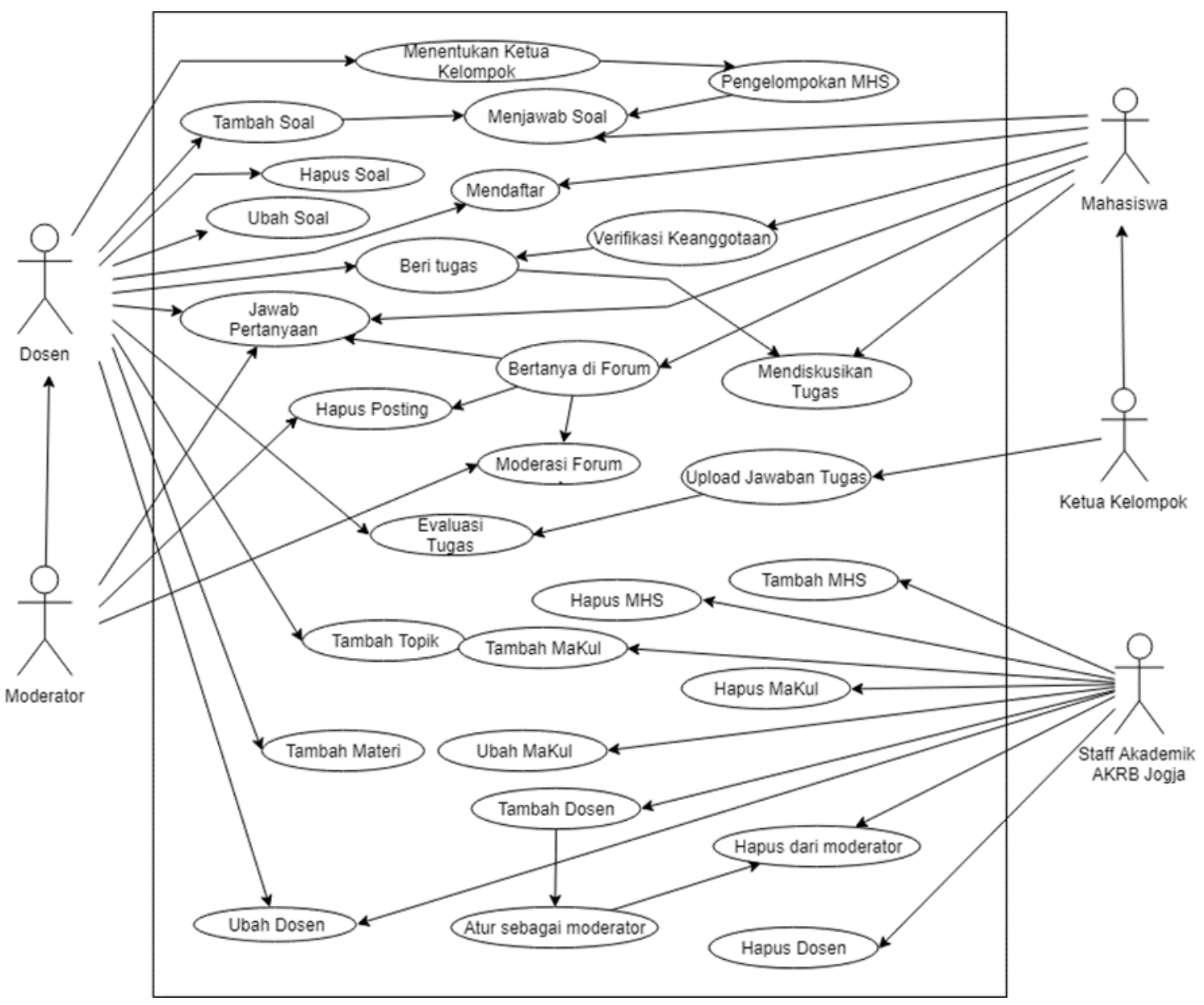

Gambar 4. Pemodelan Bisnis 


\subsubsection{Kolom Proses (How)}

Baris business concepts untuk kolom proses menggambarkan logika procedural dan bagaimana interaksi aktor terhadap proses pada LMS. Gambar 5 menjabarkan bagaimana hubungan dan interaksi pengguna/aktor terhadap proses yang terjadi pada LMS.

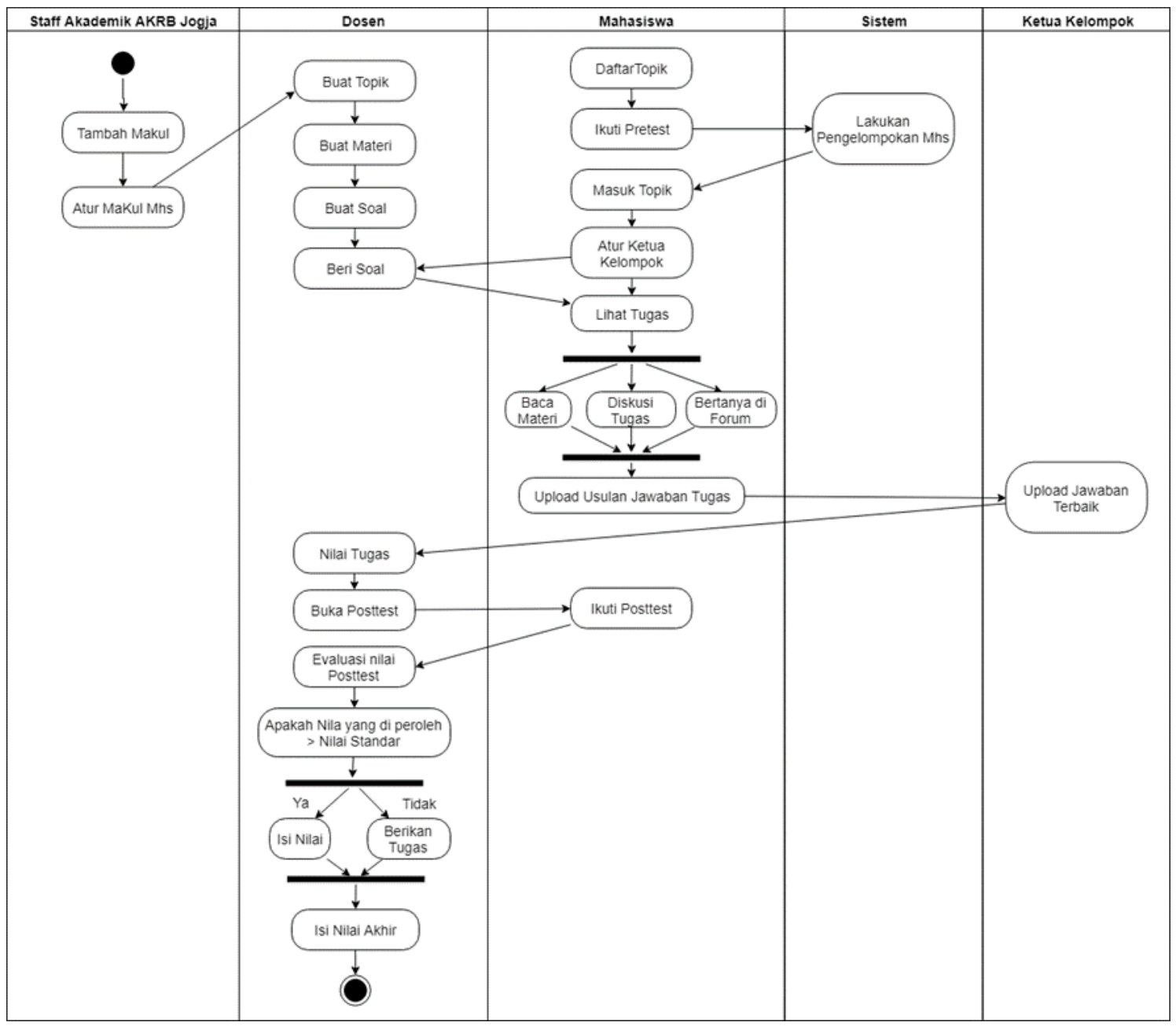

Gambar 5. Detail Interaksi Pengguna terhadap Proses pada Objek Learning Management System 
Citec Journal, Vol. 6, No. 1, Januari 2019

\subsubsection{Kolom Network (Where)}

Baris business concepts untuk kolom jaringan/network akan diuraikan desain jaringan yang sedang berjalan. Gambar 6 menunjukkan desain jaringan yang berjalan di AKRB.

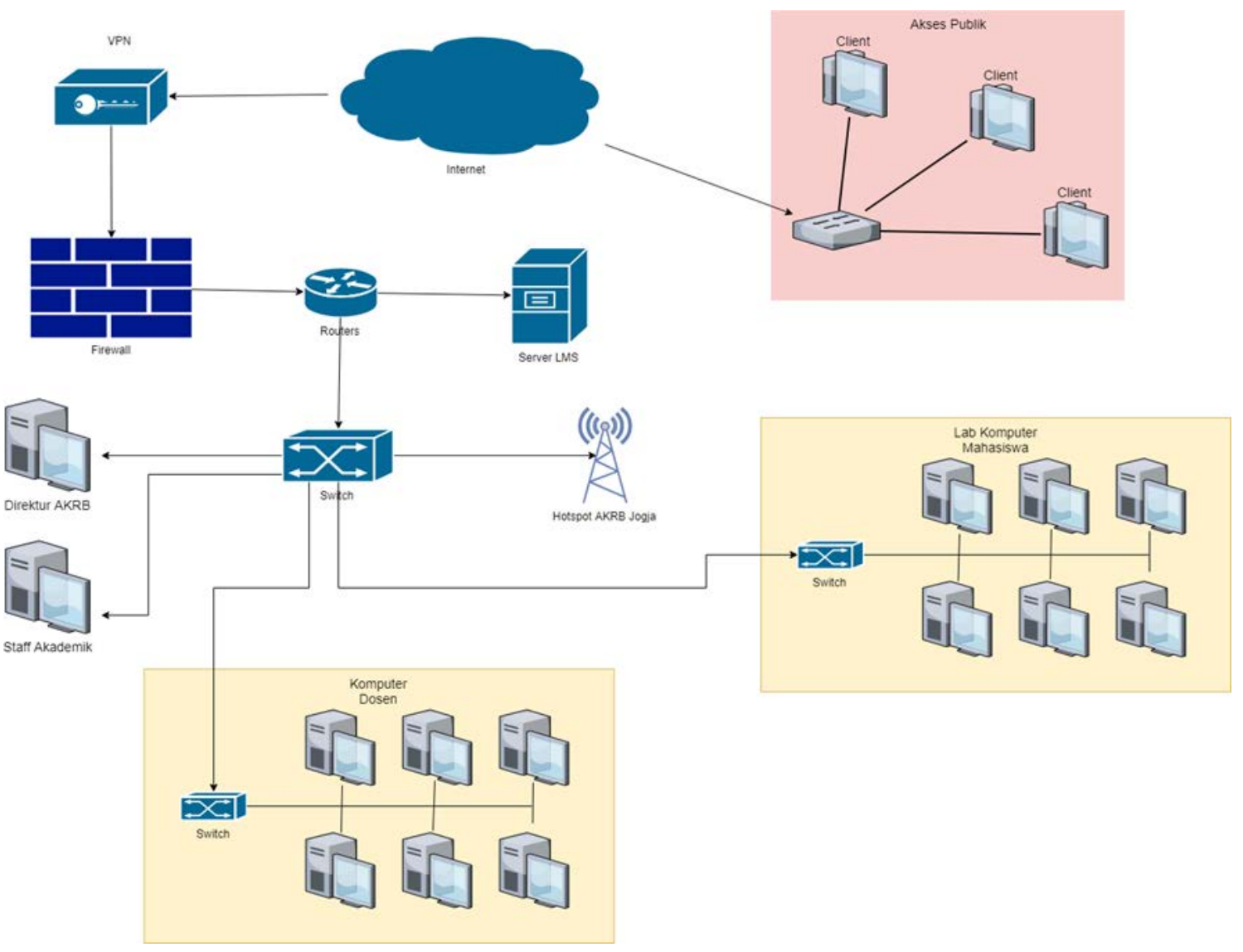

Gambar 6. Desain Jaringan AKRB

\subsection{Baris 3 - System Logic/Architects as Designers}

Penjabaran baris Scope Context/Strategist as Theorists dan Business Concepts/Executive Leaders as Owners telah dilakukan secara detail, maka langkah berikutnya adalah identifikasi sistem dari perspektif arsitek/System Logic. Kolom yang akan diidentidikasi meliputi data, proses dan jaringan learning management system.

\subsubsection{Kolom Data (What)}

Baris system logic untuk kolom data mendeskripsikan keterikatan objek pada sistem LMS. Penjabaran keterikatan objek dengan sistem disajikan dengan class diagram yang akan mencerminkan bentuk model data LMS. Gambar 7 menjabarkan keterikatan objek pada sistem LMS. 


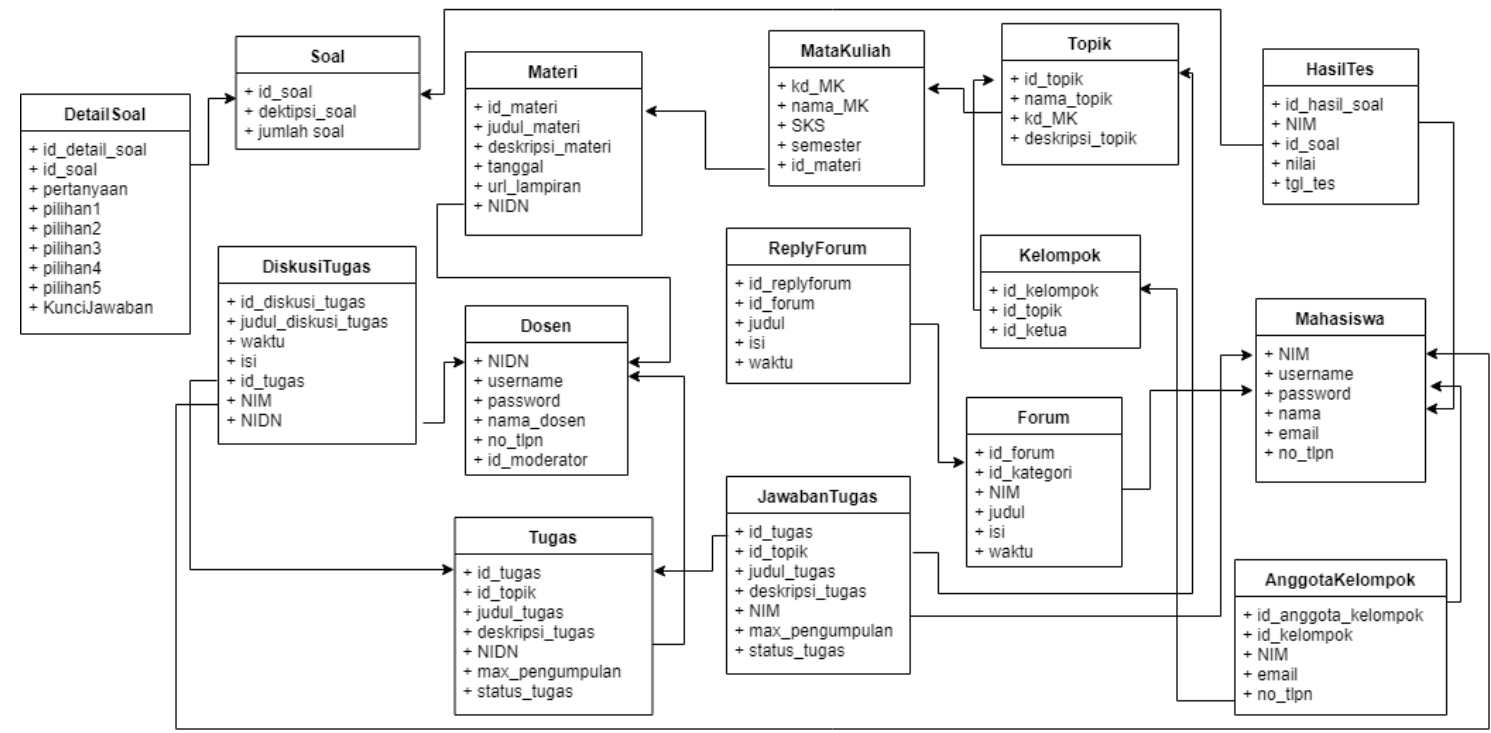

Gambar 7. Class Diagram Learning Management System

\subsubsection{Kolom Proses (How)}

Baris system logic untuk kolom proses akan menggambarkan bagaimana proses interaksi aktor dengan sistem. Penggambaran proses aktor dengan sistem akan disajikan dalam bentuk sequence diagram. Gambar 8 menunjukkan salah satu proses aktor dosen dalam proses menambah soal pada learning management system yang digambarkan dengan sequence diagram.

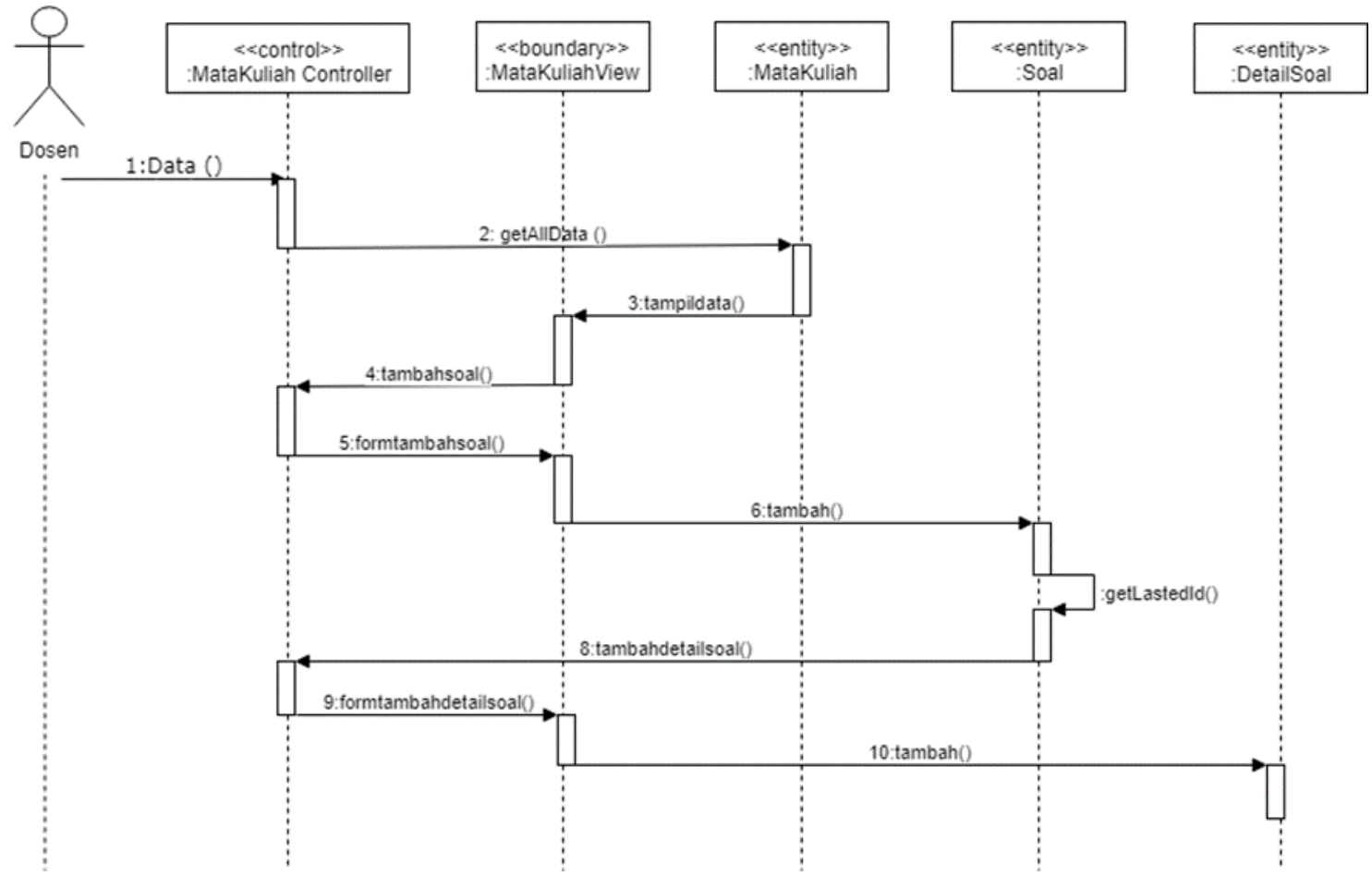

Gambar 8. Sequence Diagram Menambah Soal Leaning Management System AKRB 
Citec Journal, Vol. 6, No. 1, Januari 2019

ISSN: 2460-4259

\subsubsection{Kolom Network (Where)}

Baris system logic untuk kolom jaringan/network akan diuraikan bagaiamna desain jaringan yang diusulkan. Gambar 9 menunjukkan desain usulan LMS di AKRB.

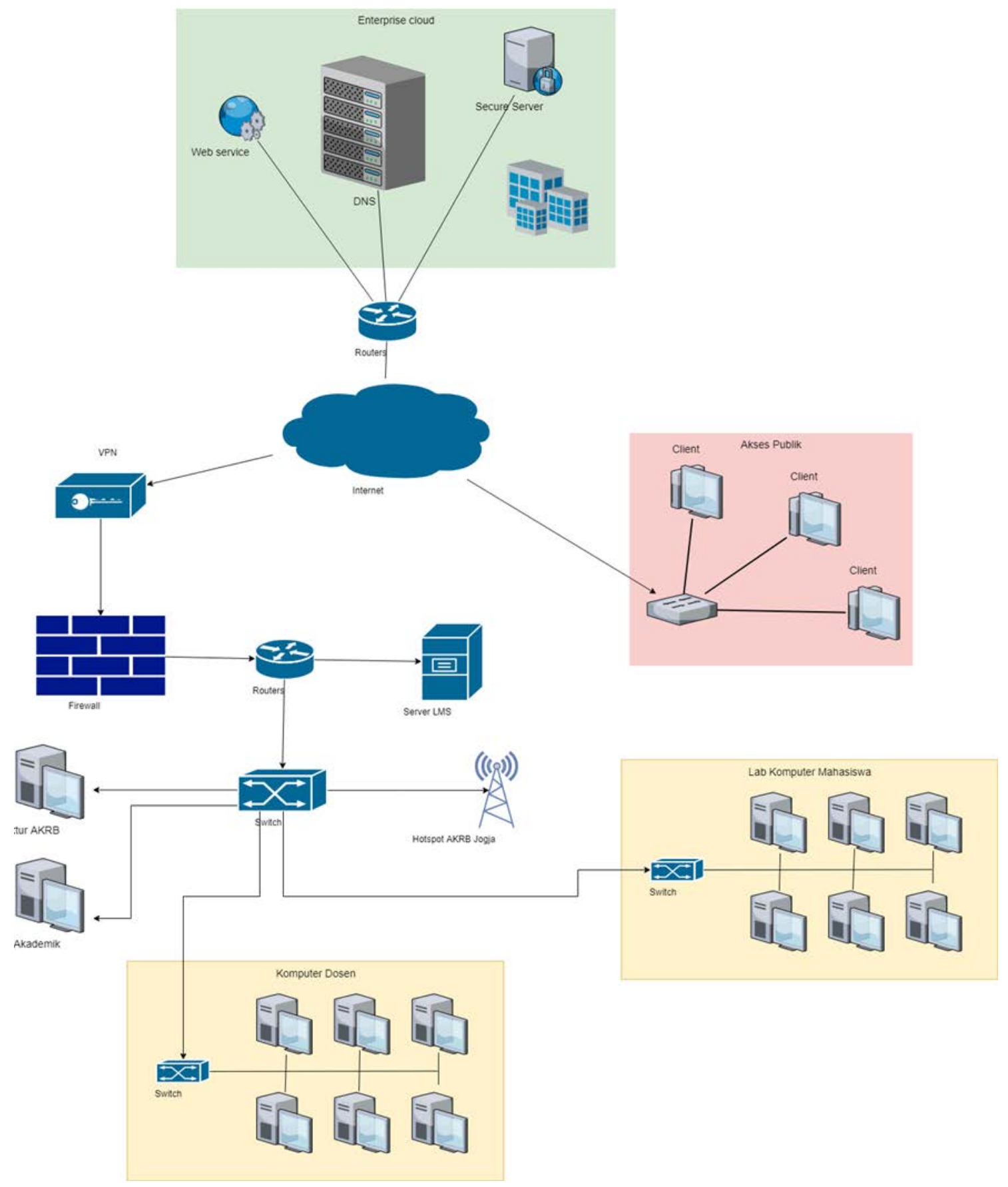

Gambar 9. Desain Jaringan Usulan LMS 


\section{KESIMPULAN}

Berdasarkan pengumpulan data dan analisis data yang telah dilakukan, penulis dapat menarik kesimpulan sebagai berikut:

1. Rancangan LMS dengan mengimplementasikan kerangka kerja Zachman menghasilkan analisa kebutuhan data, hasil analisa kebutuhan proses, dan konfigurasi komputer. Dari analisa kebutuhan data, telah dihasilkan klasifikasi data yang akan digunakan pada sistem, yaitu data dosen, data mahasiswa, data mata kuliah, data materi kuliah, dan data tugas perkuliahan.

2. Rancangan bisnis model menghasilkan diagram UML yang meliputi usecase diagram, class diagram, activity diagram dan sequence diagram. Pada usecase diagram mencakup 5 aktor yaitu dosen, moderator, ketua kelompok, mahasiswa, dan staff akademik AKRB Jogja.

3. Rancangan model logikal menghasilkan class diagram yang mencakup 15 class, yaitu class soal, detail soal, diskusi tugas, materi, dosen, tugas, matakuliah, reply forum diskusi, jawaban tugas, topik perkuliahan, kelompok, forum diskusi, hasil tes, mahasiswa dan anggota kelompok.

4. Rancangan jaringan menghasilkan desain jaringan yang menggunakan enterprise cloud guna menunjang performance LMS.

\section{SARAN}

Agar penelitian dimasa mendatang lebih baik, beberapa saran yang dapat diambil antara lain:

1. Pengisian untuk setiap sel pada matrik kerangka kerja Zachman diperlukan ketelitian yang tinggi, cermat, konsisten, dan terurut sehingga tidak terjadi tumpang tindih dalam pengisian satu sel dengan sel lainnya karena masing-masing sel akan menjadi acuan pengisian sel pada sudut pandang berikutnya.

2. Pengisian sel matrik pada kerangka Zachman perlu dilengkapi hingga perspektif technology model, detail representation, dan fungsioning enterprise sehingga dapat dilakukan implementasi dengan pembuatan aplikasi baik web based application dan windows form application yang dapat dilanjutkan dengan pengujian sistem sehingga dapat menunjang visi dan misi suatu organisasi.

\section{DAFTAR PUSTAKA}

[1] Tafiardi, 2005, Meningkatkan Mutu Pendidikan Melalui E-Learning., Jurnal Pendidik. Penabur, Vol. IV, No.04.

[2] Munir, 2009, Pembelajaran Jarak Jauh Berbasis Teknologi Informasi dan Komunikasi, Cv. Alfabeta, Bandung.

[3] Muhammad, T., 2017, Perancangan Learning Management System Menggunakan Konsep Computer Supported Collaborative Learning, Jurnal Produktif, Vol. 1, Hal. 35-63.

[4] Mustafa, P. Y. D., Jusak., Erstiawan, M. S., 2018, Rancang Bangun Aplikasi Learning Management System Berbasis Web Dengan Menggunakan Model SCORM Pada SMA Kartika, Jurnal SistemInformasi dan Komputer AKuntansi, No. 1, Vol. 7, Hal. 1-12.

[5] Sudrajat, A. W., 2015, Penerapan Framework Zachman Dalam Perancangan Arsitektur Sistem Manajemen Penyusunan Anggaran Keuangan Daerah (Studi Kasus UPTD Graha Teknologi Sriwijaya), Citec Journal., No. 1, Vol. 2, Hal. 39-50.

[6] Wisandra, A., 2019, Pemodelan Sistem Informasi Senayan Library Management System (SLIMS) dengan Framework Zachman, Jurnal Ensiklopedia, vol. 1, no. 2, pp. 1-5. 
Citec Journal, Vol. 6, No. 1, Januari 2019

[7] Ellis, R. K., 2009, A Field Guide to Learning Management System. ASTD in: American Society for Training \& Development.

[8] Wismaningrum, S. K., 2007, Perancangan Model Content Authoring Tools Berbasis SCROM (Sharable Content Object Reference Model) pada Sistem E-Learning I-Elisa, Tesis, Fakultas Teknik Universitas Gadjah Mada, Yogyakarta

[9] Setiawan, E. B., 2009, Pemilihan EA Framework, Seminar Nasional Aplikasi Teknologi Informasi 2009 (SNATI 2009), Yogyakarta, 20 Juni

[10] Schekkerman, J., 2003, How to Survive in the Jungle of Enterprise Architecture Frameworks, Trafford Publishing, Victoria

[11] Hay, D. C., Data Model Patterns: a Metadata Map, Morgan Kaufmann Publishers, San Francisco. 